\title{
$R B$ gene product levels measured by a specific radioimmunoassay decrease in regenerating rat liver after partial hepatectomy
}

\author{
Nobuo Kurokawa ${ }^{1}$, Yoshihiko Hirotani ${ }^{1}$, Noriko Takashima ${ }^{1}$, Masayoshi Sawada ${ }^{1}$, Kazuaki \\ Iguchi $^{2}$, Noboru Yanaihara ${ }^{2}$, Yukio Arakawa ${ }^{1}$ and Chizuko Yanaihara ${ }^{1}$ \\ ${ }^{1}$ Laboratory of Pharmaceutical Sciences, Osaka University School of Medicine, Yamadaoka, Suita, Osaka 565 , and ${ }^{2}$ Laboratory of \\ Bioorganic Chemistry, School of Pharmaceutical Sciences, University of Shizuoka, Yata, Shizuoka 422, Japan
}

\begin{abstract}
We have analyzed quantitatively the retinoblastoma susceptibility gene $(R B)$ product $(R B-\mathrm{P})$ in regenerating rat liver by a specific radioimmunoassay. The assay system was developed using a synthetic peptide corresponding to the $901-928$ sequence of $R B-P$ as haptenic immunogen and standard antigen, ${ }^{125} \mathrm{I}-4$-hydroxyphenylpropionyl $R B$-P (901-928) as tracer and anti- $R B$-P (901-928) serum R0811. The antiserum proved to recognize a $110 \mathrm{kDa}$ component in rat liver extract by immunoblot analysis. $R B-\mathrm{P}$ in regenerating rat liver measured by the radioimmunoassay $(R B$-P-IR) was found to decrease significantly on day 1 (to $53.5 \pm 11.6 \%$, mean \pm SEM, $P<0.01)$, day $2(74.8 \pm 11.3 \%, P<0.05)$, day $3(75.1 \pm 11.2 \%$, $P<0.05)$ and day $4(61.0 \pm 10.2 \%, P<0.01)$. The decrease was most pronounced on day 1 when DNA synthesis of hepatocytes is most active during regeneration. The level of $R B$-P-IR returned to the control level on day 6 when liver regeneration was almost completed. The time course of the reduction in $R B$-P-IR roughly paralleled that of the increase in c-myc product measured by a radioimmunoassay in our previous study (14). The present study revealed a quantitative change in $R B$-P-IR during the course of rat liver regeneration after partial hepatectomy which involves a highly synchronized replication response of a major population of hepatocytes.
\end{abstract}

The retinoblastoma susceptibility gene $(R B)$ has been known as a growth suppressor gene. The product of the gene $(R B-P)$ has been detected in all mammalian cells examined (3), and the protein has been implicated to play a role in normal cell growth $(1,3,16)$. Biochemical and immunohistochemical studies have demonstrated the nuclear localization of $R B$-P $(16,19,25)$ and the protein, like c-myc, N$m y c, c-m y b$ and c-fos proteins, is accepted as a nuclear protein with DNA binding activity (26). Regeneration of rat liver after partial resection has been used for studies of growth- and proliferationrelated gene expression in normal cells under in vivo condition $(4,7,9,10,12,13,17,22-24)$. We have previously shown the characteristic increases in immunologically measurable c-myc and c-fos products (c-myc-P-IR and c-fos-P-IR, respectively) in regenerating rat liver after partial resection (14).
In the present study, we developed a radioimmunoassay specific to $R B$-P using synthetic peptides, and examined changes in $R B$-P in regenerating rat liver after partial hepatectomy. The synthetic peptide used as haptenic immunogen corresponds to the C-terminal 901-928 sequence of $R B$ $\mathrm{P}$ which has been predicted to be one of the most hydrophilic regions of the molecule $(8,15,16)$.

Adult male Wistar rats $(180-200 \mathrm{~g})$ were subjected to partial $(70 \%)$ hepatectomy or sham-operation under ether anesthesia by the method of Higgins and Anderson (11). Liver tissue was extracted by homogenizing with a Bio-Mixer model BM-1 in 5 vol of ice-cold $50 \mathrm{mM}$ Tris- $\mathrm{HCl}$ buffer (pH 7.4) containing $5 \%$ glycerol, $50 \mathrm{mM} \mathrm{NaCl}, 1 \mathrm{mM}$ phenylmethylsulfonylfluoride (PMSF), $250 \mathrm{KIU} / \mathrm{ml}$ aprotinin, $0.01 \%$ soybean trypsin inhibitor (SBTI), $0.1 \%$ bacitracin and $50 \mathrm{mM}$ EDTA. The homog- 
enate was centrifuged at $160,000 \mathrm{~g}$ for $1 \mathrm{~h}$ at $4^{\circ} \mathrm{C}$ and the supernatant was taken. Protein concentration was determined by the method of Bradford (2). Gel filtration of the tissue extract was carried out on a column $(1.6 \times 96 \mathrm{~cm})$ of Sepharose $6 \mathrm{~B}$ with $50 \mathrm{mM}$ Tris- $\mathrm{HCl}$ buffer (pH 7.5) containing $50 \mathrm{mM}$ $\mathrm{NaCl}, 50 \mathrm{mM}$ EDTA, $1 \mathrm{mM}$ PMSF, $0.02 \% \mathrm{NaN}_{3}$ and $0.01 \%$ SBTI. Fractions of $3.7 \mathrm{ml}$ each were collected. Syntheses of $R B-\mathrm{P}(901-928)$ and $N^{\alpha}-4$-hydroxyphenylpropionyl $R B-\mathrm{P}(901-928)$ were carried out by solid phase method using an automated peptide synthesizer ABI model 430A. RB-P (901$928)$ of high purity $(4.4 \mathrm{mg})$ was conjugated with porcine thyroglobulin $(27.3 \mathrm{mg})$ in the presence of water-soluble carbodiimide $(25.4 \mathrm{mg})$. The conjugate $(5.0 \mathrm{mg})$ emulsified with complete Freund's adjuvant $(1.5 \mathrm{ml})$ was injected to three rabbits intradermally. Injection with the conjugate was repeated every 2 weeks using a half of the initial amount of immunogen. Antiserum R0811 thus obtained was used for immunoblot analysis and radioimmunoassay. 4-Hydroxyphenylpropionyl $R B$ $\mathrm{P}$ (901-928) was radioiodinated by the chloramine $\mathrm{T}$ method. Radioimmunoassay was performed according to the method previously described (14), using antiserum R0811 (final dilution, $\times 10,500$ ), ${ }^{125} \mathrm{I}-N^{a}$-4-hydroxyphenylpropionyl $R B$-P (901-928) as tracer and $R B-\mathrm{P}(901-928)$ as standard antigen. The standard diluent used for the assay was $10 \mathrm{mM}$ phosphate buffer ( $\mathrm{pH} 7.4$ ) containing $0.5 \%$ bovine serum albumin, $50 \mathrm{mM}$ EDTA, 0.01\% SBTI, 0.1\% bacitracin, $0.1 \mathrm{mM}$ PMSF and $0.14 \mathrm{M} \mathrm{NaCl}$. SDSpolyacrylamide gel electrophoresis and immunoblot analysis of rat liver extract were carried out as previously described (14). Antiserum R0811 (dilution, $\times 3,000$ ) was used for immunoblot analysis.

Fig. 1 shows a typical standard curve in the present radioimmunoassay for $R B$-P together with a serial dilution curve of rat liver extract which was linear and parallel to the standard curve. The assay system was able to quantitate $R B-\mathrm{P}$ as low as $80 \mathrm{fmol}$. The component measurable by the radioimmunoassay system was eluted as a peak in gel filtration as shown in Fig. 2. Immunoblot analysis of this peak fraction as well as crude liver extract showed a single band corresponding to molecular weight of $110 \mathrm{kDa}$ (Fig. 3). The results indicate the existence of immunochemically detectable $R B-\mathrm{P}$ $(R B$-P-IR) in rat liver and prove the validity of the present radioimmunoassay for measurement of $R B$-P in crude rat liver extract. The change in $R B$-PIR level during liver regeneration after partial resection is shown in Fig. 4. RB-P-IR level decreased sig-

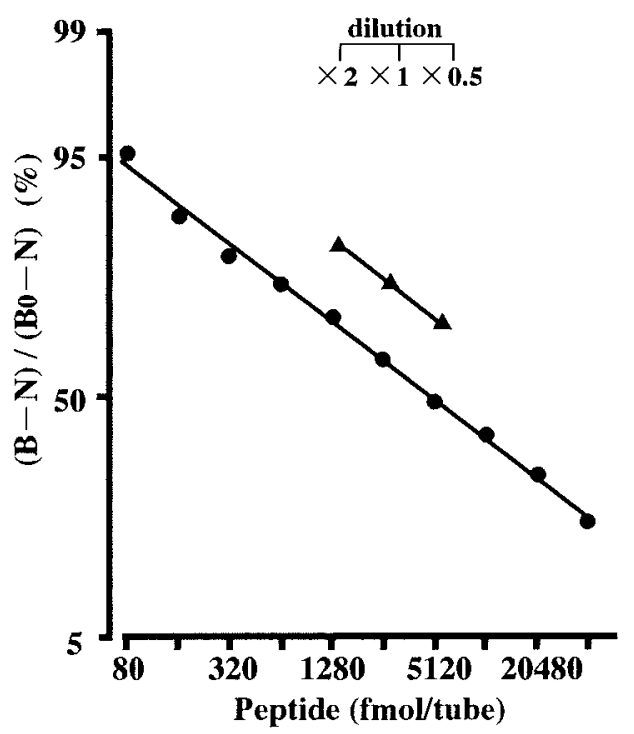

Fig. 1 A typical standard curve $(-\bullet)$ of a radioimmunoassay for $R B$-P with a dilution curve of rat liver extract $(-\mathbf{A}-)$

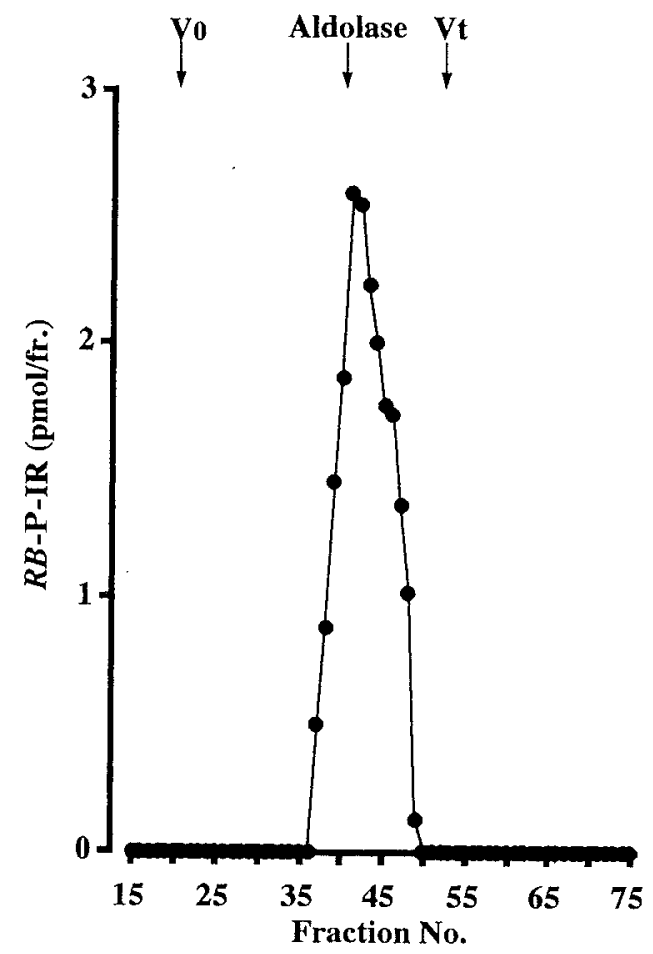

Fig. 2 Gel filtration profile on a Sepharose $6 \mathrm{~B}$ column of $R B$-P-IR in rat liver extract

nificantly on day 1 (to $53.5 \pm 11.6 \%$, mean \pm SEM, $P<0.01)$, day $2(74.8 \pm 11.3 \%, P<0.05)$, day 3 $(75.1 \pm 11.2 \%, P<0.05)$ and day $4(61.0 \pm 10.2 \%$, 


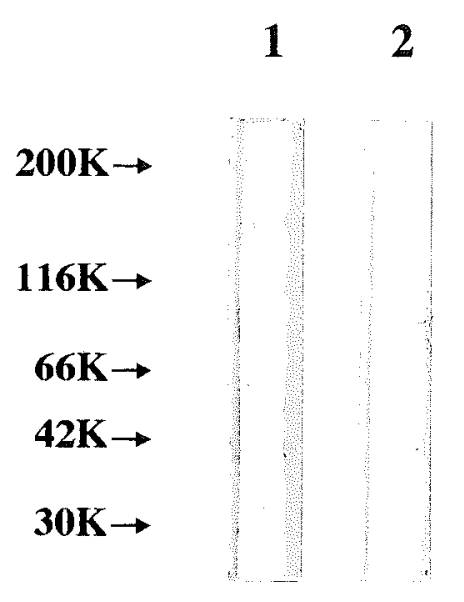

Fig. 3 Immunoblot analysis after SDS-polyacrylamide gel electrophoresis of rat liver extract (1) and the peak fraction of gel filtration (Fig. 2) of rat liver extract (2)

$P<0.01$ ). The changes in $R B$-P-IR at $3,6,12$ and $18 \mathrm{~h}$ after resection were statistically not significant.

$R B$-P-IR was found to decrease during rat liver regeneration after partial resection. The decrease was most pronounced at $24 \mathrm{~h}$ after resection when DNA synthesis in hepatocytes is known to be most active. The lowered level of $R B$-P-IR in regenerating liver persisted until day 5 . Proliferation of nonparenchymal cells lagged behind hepatocytes in time during regeneration $(5,6)$. The persistent decrease in $R B$-P-IR level with another trough on day 4 may relate to the proliferation of these cells. The level of $R B$-P-IR returned to normal on day 6 when liver regeneration was almost completed. The present study revealed an inverse relationship between the concentration changes in $R B$-P-IR and in c-myc-P-IR and c-fos-P-IR in regenerating rat liver. The time course of the reduction in $R B$-P-IR roughly paralleled that of c-myc-P-IR increase (14). Mihara and coworkers (19) have observed by an immunoprecipitation method using anti-synthetic peptide antisera that the amount of $R B-P$ per cell was increased as the cells progressively matured through the $G_{1}, S$ and $G_{2}+M$ phases of the cell cycle in HL-60 cells. However, the experimental materials and conditions used by Mihara and colleagues differed from those of the present study. Rustgi and colleagues (21) have suggested that c$m y c$ and $R B$ products cooperate through direct binding to control cell proliferation. Negative regulation of human c-fos expression by $R B$ product has also been observed in NIH/3T3 cells cotransfected

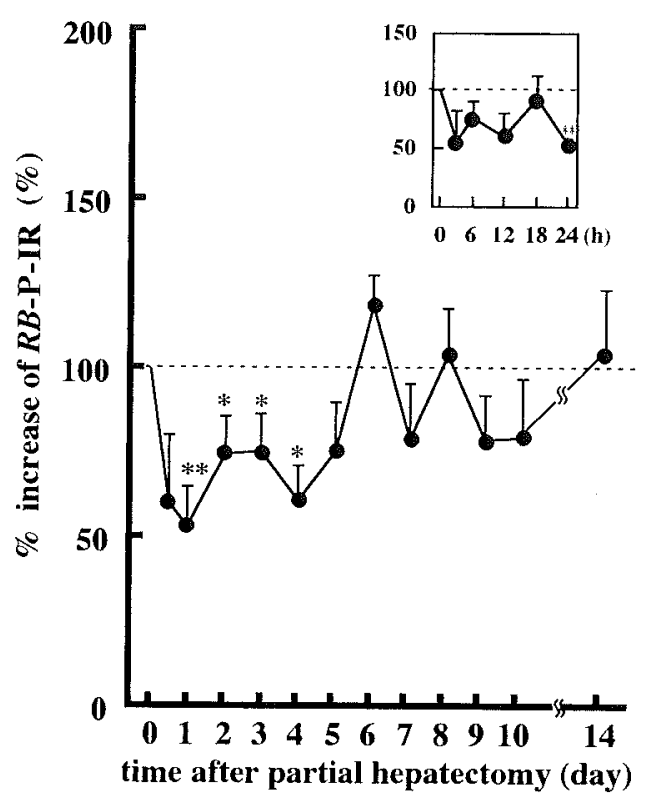

Fig. 4 Time course of percent change in $R B$-P-IR level in regenerating rat liver after partial hepatectomy (mean $\left.\pm \mathrm{SEM},{ }^{*} P<0.05,{ }^{* * *} P<0.01\right)$

with $R B$ protein expression plasmids with c-fos promoter constructs (20).

Studies on the regulation mechanism of $R B-\mathrm{P}$ activity have focused almost exclusively on the phosphorylation state of the protein. It has been reported that $R B-\mathrm{P}$ switches between hyperphosphorylated and hypophosphorylated states in a cell cycle-specific manner $(18,26)$. The present study revealed a quantitative change in $R B$-P immunochemically measured during the course of rat liver regeneration after partial hepatectomy which involves a highly synchronized replication response of a major population of hepatocytes. The decrease in $R B$-P-IR concentration in regenerating liver observed during the stage when hepatocytes and nonparenchymal cells are growing and proliferating seems to suggest the existence of a mechanism of the regulation of $R B$-P activity implicating quantitative changes in the protein.

Received 8 December 1994; and accepted 22 December 1994

\section{REFERENCES}

1. Bernards R., Schackleford G. M., Gerber M. R., Horowitz J. M., Friend S. H., Schartl M., Bogenmann E., Rapaport J. M., McGee T., Dryja T. P. and Weinberg R. A. (1989) Structure and expression of the murine retino- 
blastoma gene and characterization of its encode protein. Proc. Natl. Acad. Sci. USA 86, 6474-6478

2. BRADFoRd M. M. (1976) A rapid and sensitive method for the quantitation of microgram quantities of protein utilizing the principle of protein-dye binding. Anal. Biochem. 72, $248-254$

3. Buchkovich K., Duffy L. A. and Harlow E. (1989) The retinoblastoma protein is phosphorylated during specific phases of the cell cycle. Cell 58, 1097-1105

4. Corral M., Tichonicky L., Guguen-Guillouzo C., Corcos D., Raymondjean M., Paris B., Kruh J. and Defer N. (1985) Expression of c-fos oncogene during hepatocarcinogenesis, liver regeneration and in synchronized HTC cells. Exp. Cell Res. 160, 427-434

5. Edwards J. L. and Koch A. (1964) Parenchymal and littoral cell proliferation during liver regeneration. Lab. Invest. $13,32-43$

6. FABRIKANT J. I. (1968) The kinetics of cellular proliferation in regenerating liver. J. Cell Biol. 36, 551-564

7. Fausto N., Mead J. E., Braun L., Thompson N. L., Panzica M., Goyette M., Bell G. I. and Shank P. R. (1987) Proto-oncogene expression and growth factors during liver regeneration. In Symposium on Fundamental Cancer Research, Univ. Texas System Cancer Center, Austin, pp. 69-86

8. Friend S. H., Horowitz J. M., Gerber M. R., Wang X.-F., Bogenmann E., Li F. P. and Weinberg R. A. (1987) Deletions of a DNA sequence in retinoblastomas and mesenchymal tumors: Organization of the sequence and its encoded protein. Proc. Natl. Acad. Sci. USA 84, 9059-9063

9. Goyette M., Petropoulos C. J., Shank P. R. and Fausto N. (1983) Expression of a cellular oncogene during liver regeneration. Science 219, 510-512

10. Goyette M., Petropoulos C. J., Shank P. R. and Fausto N. (1984) Regulated transcription of c-Ki-ras and c-myc during compensatory growth of rat liver. Mol. Cell. Biol. 4, $1493-1498$

11. Higgins G. M. and Anderson R. M. (1931) Experimental pathology of the liver. I. Restoration of the liver of the white rat following partial surgical removal. Arch. Pathol. 12, 186-202

12. Hsieh L. L., Peraino C. and Weinstein I. B. (1988) Expression of endogenous retrovirus-like sequences and cellular oncogenes during phenobarbital treatment and regeneration in rat liver. Cancer Res. 48, 265-269

13. Kruijer W., Skelly H., Botteri F., van der Putten H., Barber J. R., Verma I. M. and LefFert H. L. (1986) Protooncogene expression in regenerating liver is simulated in cultures of primary adult rat hepatocytes. J. Biol. Chem. 261, 7929-7933
14. Kurokawa N., Hirotani Y., Arakawa Y., Iguchi K., Urabe N., Yanaihara N., Abe K. and Yanaihara C. (1990) Increased production of c-myc- and c-fos-related proteins during late stage of regenerative process in rat liver after partial hepatectomy. Biomedical Res. 11, 165-172

15. Lee W.-H., Bookstein R., Hong F., Young L.-J., Shew J.-Y. and LEE E. Y.-H. P. (1987) Human retinoblastoma susceptibility gene: Cloning, identification, and sequence. Science 235, 1394-1399

16. Lee W.-H., Shew J.-Y., Hong F. D., Sery T. W., Donoso L. A., Young L.-J., Bookstein R. and LeE E. Y.-H. P. (1987) The retinoblastoma susceptibility gene encodes a nuclear phosphoprotein associated with DNA binding activity. Nature 329, 642-645

17. Makino R., Hayashi K. and Sugimura T. (1984) c-myc transcript is induced in rat liver at a very early stage of regeneration or by cycloheximide treatment. Nature 310, 697-698

18. Marshall C. J. (1991) Tumor suppressor genes. Cell 64, 313-326

19. Mihara K., Cao X.-R., Yen A., Chandler S., Driscoll B., Murphree A. L., T’Ang A. and Fung Y.-K. T. (1989) Cell cycle-dependent regulation of phosphorylation of the human retinoblastoma gene product. Science 246, 13001303

20. Robbins P. D., Horowitz J. M. and Mulligan R. C. (1990) Negative regulation of human c-fos expression by the retinoblastoma gene product. Nature 346, 668-671

21. Rustgi A. K., Dyson N. and Bernards R. (1991) Aminoterminal domains of $c-m y c$ and $\mathrm{N}-m y c$ proteins mediate binding to the retinoblastoma gene product. Nature 352 , $541-544$

22. Sillerman J. A., Zurlo J., Watson M. A. and Yager J. D. (1989) Expression of c-raf-1 and A-raf-1 during regeneration of rat liver following surgical partial hepatectomy. $\mathrm{Mol}$. Carcinogenesis 2, 63-67

23. Sobczak J., Tournier M.-F., Lotti A.-M. and Duguet M. (1989) Gene expression in regenerating liver in relation to cell proliferation and stress. Eur. J. Biochem. 180, 49-53

24. Thompson N. L., Mead J. E., Braun L., Goyette M., Shank P. R. and Fausto N. (1986) Sequential protooncogene expression during rat liver regeneration. Cancer Res. 46, 3111-3117

25. Varley J. M., Armour J., Swallow J. E., Jefrreys A. J., Ponder B. A. J., T’Ang A., Fung Y.-K. T., Brammar W. J. and WALKER R. A. (1989) The retinoblastoma gene is frequently altered leading to loss of expression in primary breast tumours. Oncogene 4, 725-726

26. Weinberg R. A. (1991) Tumor suppressor genes. Science. 254, 1138-1146 